\title{
Using COPE to improve quality of care: The experience of the Family Planning Association of Kenya
}

Janet Bradley

Judith Bruce

Population Council

Soledad Diaz

Carlos Huezo

Kalimi Mworia

Follow this and additional works at: https://knowledgecommons.popcouncil.org/departments_sbsr-pgy

Part of the Family, Life Course, and Society Commons, International Public Health Commons, Public Health Education and Promotion Commons, and the Women's Health Commons How does access to this work benefit you? Let us know!

\section{Recommended Citation}

Bradley, Janet, Judith Bruce, Soledad Diaz, Carlos Huezo, and Kalimi Mworia. 1998. "Using COPE to improve quality of care: The experience of the Family Planning Association of Kenya," Quality/Calidad/ Qualité no. 9. New York: Population Council. 
DOHT BE ₹ COOLF?

AIDS IS

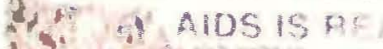

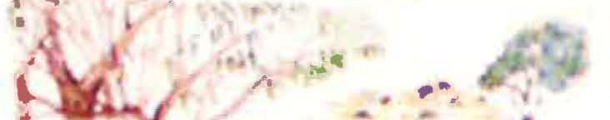

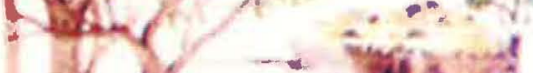

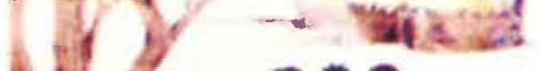

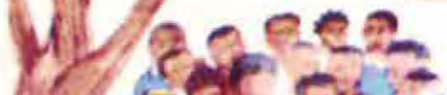
afores?

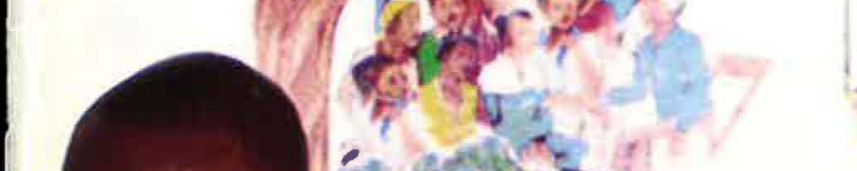

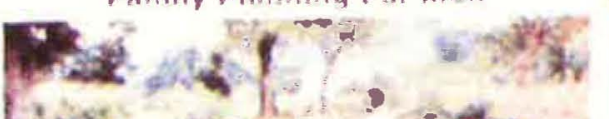

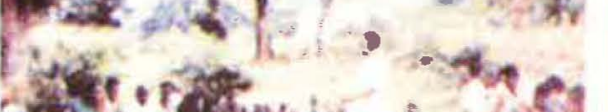
ate

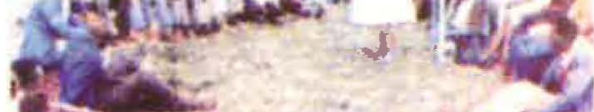

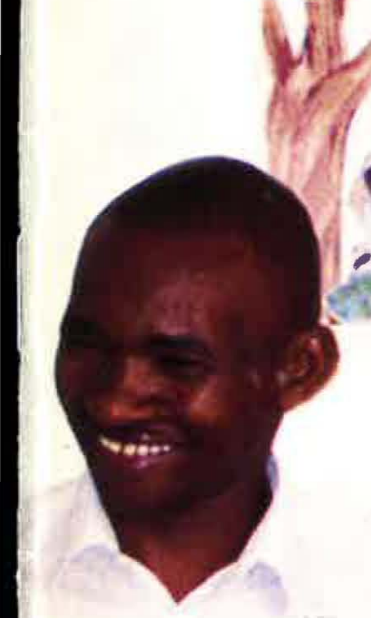




\section{Quality/Calidad/Qualité}

Quality/Calidad/Qualité, a publication of the Population Council, highlights examples of family planning and reproductive health programs that are providing unusually high quality care. This series is part of the Council's Robert H. Ebert Program on Critical Issues in Reproductive Health which, through scientific and practical efforts, seeks to improve and expand the scope and quality of reproductive health care. The philosophical foundation of the program, and of this series, is that women and their partners have a fundamental right to respectful treatment, information, choice, and follow-up from reproductive health care providers. The pamphlets reflect one of the four main thrusts of the program: enhancing the quality of family planning programs.

Projects are selected for documentation in the Quality/Calidad/Qualité series by an Advisory Group made up of individuals who have a broad range of experience within the field of reproductive health and are committed to improving the quality of services. These projects are making important strides in one or more of the following ways: broadening the choice of contraceptive methods and technologies available; providing the information clients need to make informed choices and better manage their own health care; strengthening the quality of client/provider interaction and encouraging continued contact between providers and clients; making innovative efforts to increase the management capacity and broaden the skills of service providers at all levels; expanding the constellation of services and information provided beyond those conventionally defined as "family planning"; and reaching underserved and disadvantaged groups with reproductive health care services.

None of the projects documented in the series is being offered as a model for replication. Rather, each is presented as an unusually creative example of values, objectives, and implementation. These are "learning experiences" that demonstrate the self-critical attitude required to anticipate clients' needs and find affordable means to meet them. This reflective posture is exemplified by a willingness to respond to changes in clients' needs as well as to the broader social and economic transformations affecting societies. Documenting the critical choices these programs have made should help to reinforce, in practical terms, the belief that an individual's satisfaction with reproductive health care services is strongly related to the achievement of broader health and population goals.

Publication of this edition of Quality/Calidad/Qualité is made possible by support provided by the Ford Foundation, the John D. and Catherine T. MacArthur Foundation, and the Rockefeller Foundation.

Statements made and views expressed in this publication are solely the responsibility of the authors and not of any organization providing support for Quality/Calidad/Qualité. Any part of this document may be reproduced without permission of the authors so long as it is not sold for profit.

Number Nine 1998 ISSN 1097-8194 Copyright (C) 1998 by The Population Council, Inc.

\section{Population Council}

The Population Council is an international, nonprofit, nongovernmental institution that seeks to improve the wellbeing and reproductive health of current and future generations around the world and to help achieve a humane, equitable, and sustainable balance between people and resources. The Council conducts biomedical, social science, and public health research and helps build research capacities in developing countries. Established in 1952, the Council is governed by an international board of trustees. Its New York headquarters supports a global network of regional and country offices.

Population Council, One Dag Hammarskjold Plaza, New York, New York 10017 USA

tel: (212) 339-0500, fax: (212) 755-6052, e-mail: pubinfo@popcouncil.org, http://www.popcouncil.org 


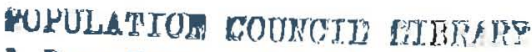 \\ I Dag Hammarskjold Plezm \\ Using COPE to Improve Quality of Care: The Experience of the \\ Family Planning Association of Kenya
}

\author{
by Janet Bradley \\ Introduction by Judith Bruce, Soledad Diaz, \\ and Carlos Huezo \\ Afterword by Kalimi Mworia
}

\begin{abstract}
A Note to the Reader: This is the first of several editions of Quality/Calidad/Qualité that will describe methodologies designed to assist family planning program managers and staff to self-assess the quality of services they are providing. These tools give program sponsors an opportunity to identify shortfalls in their service environment and propose solutions. In this issue, we focus on AVSC International's COPE (client-oriented, provider-efficient) methodology, a self-assessment tool that has now been used in 35 countries around the world.
\end{abstract}

\section{Introduction}

The 1994 International Conference on Population and Development (ICPD) advocated a client-centered approach to the delivery of servicess-placing individual needs at the center of all family planning and reproductive health programs. Utimately, the front-line providers of care are the ones who bear the responsibility for translating the language of Cairo into action. In adopting a clientcentered approach, providers now need to bë aware of their clients' social context and individual needs, as well as being respectful of their rights and their ability to make informed decisions. However, more often than not, nothing in the training providers receive, let alone the structure within which they work, has prepared them to operate in this fashion. Furthermore, when no one is respectful of the providers' capabilities or rights, howgean they be expected to relate empathetically to, and be concemed about the rights of their clients?

Program management bears the responsibility for many of the limitations exhibited by clinic personnel. Not only do providers receive insufficient or inadequate training and technical guidelines, but supervisors often take a critical stance, addressing only issues of technical competence and achievement of quantitative program goals. Clinic staff are routinely excluded from contributing to the definition of policies and strategies; their opinions and concerns are rarely sought and routinely overlooked. Yet, at the end of the day, they take the blame for shortfalls in program performance and the resulting poor quality of care.

AVSC International's COPE methodology, and the bold and sometimes punishing applications it has been put through by the Family Planning Association of Kenya (FPAK), provide a wonderful example of what the process of improving care really looks like. It looks like experimentation. It looks like recognition of past, system-wide failures - without assigning blame. And it looks like a willingness to start over, to try again, and to continue moving ahead.

Although COPE may not be the only way to actively involve providers in determining how care can be improved, it is an approach that has a demonstrated ability to move individuals and organiza- 
tions in the direction of developing practical solutions to a wide range of problems. In the Kenyan example presented here, COPE has been applied with flexibility and imagination. Top managers have had to loosen their control of the methodology, with the result that clinic-level staff have come to see COPE as their own tool, one that they can modify and that they can employ in order to better serve their clients and increase their own level of job satisfaction.

COPE involves a process that legitimately invests power with providers and clinic-level staff, and is based on the notion of clients' rights. It gives providers more control over their environment, more scope to take initiative, and more authority over logistics such as supplies and key aspects of finances. In sum, it allows them to make judgments and take responsibility outside of strict hierarchical boundaries. Second, it allows providers to feel a natural identification with their clients, to understand their sense of powerlessness, exclusion, and frustration. Providers are sometimes clients themselves, and many have chosen to work in a service profession because they want to help others. Unfortunately, to date, few management techniques have recognized or built upon this natural affinity. The use of COPE has also fostered a willingness to talk openly about several former. "unmentionables": for example, the poor levels of protection against infection found in many family planning clinics and program emphasis on longer-term, often invasive modern methods such as the IUD, injectables, and permanent voluntary surgical contraception, in an environment of increasing levels of sexually transmitted infections (STIs) including HIV/AIDS.

On paper, COPE appears to be clinic-centered, thus leading to the question, how can COPE exercises, which are conducted in individual clinics, bring about systematic change? Use of COPE is nevertheless validating the rhetoric of ICPD, reinforcing messages that are starting to seep out across the landscape: the importance of method choice, the importance of offering more complete information, the importance of confidentiality and the individual's right to privacy, and the fundamental importance of safe care. In Kenya, this process is exemplified by close cooperation between FPAK and the Ministry of Health and the generally comfortable association between government and nongovernmental organizations in an atmosphere conducive to experimentation. (Kenya was also the country where the first situation analysis study was carried out.) The result is that these self-assessment exercises are, in fact, resulting in system-wide quality improvement. The commitment and enthusiasm of the sponsoring organization to allow the process of change to move forward, and its enthusiasm for the COPE process has allowed a potentially limited self-assessment exercise to become a dynamic force of change affecting the entire health system. Today, quality improvement is not only a key element in FPAK's strategic plan, but also in the 1995 National Implementation Plan for Family Planning of the Kenyan Ministry of Health (MOH).

Ultimately, the strength of the process is a testimony to the honesty of service providers and their capacity to become the engines of change. Long after the impact studies of quality of care are finished, the priorities of donors have shifted, and the conclusions of international conferences are forgotten, the enduring focal point for change will remain the providers themselves. These are people who simply want to wake up in the morning and feel good about going to work and doing a job that they know is useful and appreciated. Thus COPE is hitting just the right pitch in terms of mobilizing clinic staff as a constituency for improved care and for a more humane and responsive health system. 


\section{The Family Planning Association of Kenya}

The Family Planning Association of Kenya (FPAK) began in 1961 as a group of volunteers seeking to raise awareness about family planning within the government and the community. That year, FPAK became the first family planning association in Africa to join the International Planned Parenthood Federation (IPPF). By 1969, FPAK opened its first model clinic and began recruiting staff. Progress was slow: Throughout the 1970s, the focus of activities was on educating and motivating women to use contraceptives.

By the end of the 1970s, an increasing number of women began using family planning methods and, during the 1980s, the role and coverage of government and mission hospitals increased substantially. FPAK was able, therefore, to diversify its activities, and experiment with specific program components such as services for youth and for men; community-based distribution (CBD) programs; development of information, education, and communication (IEC) strategies; improvement of service quality; and expansion of reproductive health programming. These activi- ties, as well as the subsequent introduction of COPE, were frequently undertaken with the support of the Kenyan Ministry of Health (MOH). "FPAK is independent, but is seen as a sort of arm of the Ministry of Health," says Jane Asila, Senior Trainer in the MOH Division of Family Health. "If we want to explore new areas, then FPAK is always willing to pilot-test for us, to try new things, and to evaluate new strategies."

FPAK now operates with an annual budget of more than 300 million Kenya shillings (US $\$ 5$ million) and a full-time paid staff of 250 (most of whom support the CBD program in the field; 100 work in the clinics). FPAK has a varied program, yet more than 50 percent of its budget is still reserved for family planning services. The organization supports 14 reproductive health clinics that offer family planning, Pap smear screening, pregnancy testing, breast examination, and screening (including laboratory testing) and treatment of sexually transmitted infections (STIs). In addition, three new clinics funded under the IPPF's Vision 2000 program are offering services exclusively for men. FPAK offers CBD services through a network of over 1,000 volunteers working in 21 sites throughout the country and manages two advice

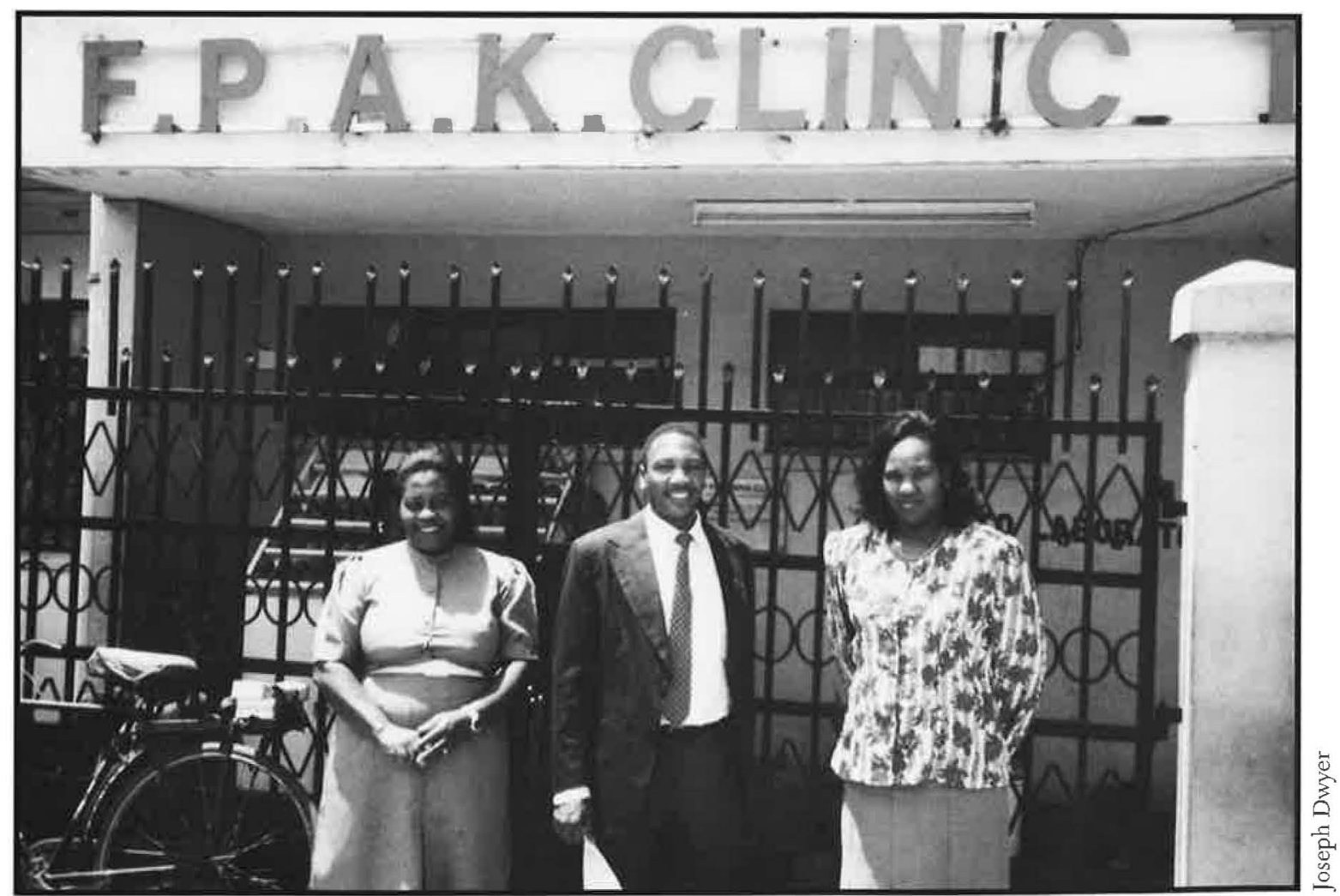


centers for young people. A recent initiative is the gender project through which FPAK, together with Plan International, is developing an advocacy program to address such issues as early marriage and female genital mutilation. Efforts to develop a postabortion care program within the organization are also under way.

During the 1980s, FPAK forged an alliance with the New York-based nongovernmental organization (NGO), AVSC International, to introduce such clinical innovations as minilaparotomy under local anesthesia. In time, FPAK became a key clinical training center for the introduction of new technologies, including Norplant ${ }^{\circledR}$ contraceptive implants. Subsequent FPAK and AVSC evaluations of the care offered in delivery of these new technologies, however, revealed shortfalls in both technical and interpersonal aspects of care. This evaluation took place during a time when criteria for program success were beginning to be defined in terms of what clients were actually receiving rather than in terms of the range of technologies offered. Clearly, there was a need to train both a wider range of practitioners and expand the content of the training itself to include more than technical skills.

\section{Early Attempts At Improving Quality of Care}

"I think we first started talking about quality of care in the mid-1980s," says Godwin Mzenge, Executive Director of FPAK in Nairobi. "We had always prided ourselves on providing highquality services, but we realized that there were gaps: We were not fully prepared for dealing with the HIV epidemic and related safety concerns; we did not have defined basic standards of care; we didn't do enough quality counseling; clients were waiting a long time in the clinics; we realized that there were many medical barriers. We knew we needed to do something, but what?"

One of the first attempts to improve quality was to look at client waiting times, using a client flow analysis (CFA) in five FPAK clinics. "We used the Centers for Disease Control (CDC) computer program and indeed identified waiting times as a major problem," says Dr. Isaac Achwal, Senior Program Manager with FPAK. "However, as we didn't have a computer and, as the process was so complex, we couldn't repeat the CFA widely and had to abandon it. We needed something simpler that staff could use themselves on an ongoing basis."

In 1986, FPAK organized its first quality improvement meeting for program officers and service providers, but the outcome was less than encouraging. "We decided to start to look at our problems, but all we achieved was everyone blaming everyone else. The supervisors blamed the clinics, the clinics blamed the supplies department, the supplies department blamed the area managers, the area managers blamed the doctors, and the doctors blamed the nurses. Everyone had a story about someone else and nobody had anything constructive to say or understood anyone else's constraints." The search for someone to blame made staff defensive, and it quickly became clear that there was a basic lack of trust among them; people were afraid to make decisions or take responsibility.

Other early attempts at a solution revolved around developing guidelines and basic standards for clinical practice, developing counseling curricula, training staff, and developing supervisory checklists. Around this time, FPAK also developed a logo stating that "A client is always right," but the effort remained rhetorical and mechanical. FPAK annual meetings duly focused on quality yet, despite initial enthusiasm among the staff, no one could agree upon a definition of "quality improvement" and no sense of collective effort emerged. Dr. Achwal and his colleagues realized that they needed to rethink their approach and develop a nonthreatening framework for the discussion of problems. Dr. Achwal now recalls that they were, in fact, "trying to legislate quality."

"The area managers (regional supervisors) were not even invited to the annual planning meetings at first," says Godwin Mzenge. "They felt left out and were unsupportive of the changes that clinic staff were trying to make. Besides, the idea of focusing everything on the client ignored the needs of the providers; in effect, [this focus] continued to 'blame' the providers for the inadequacies of the program." This divisiveness was inadvertently fueled by a decision to use staff from "good" clinics to help other clinics. It was at this point that FPAK began to realize that people were not the problem. Rather, the problem was the unsupportive, overly centralized and sometimes punitive system in which they worked which created an atmosphere in which issues could not be frankly discussed nor could imaginative changes be proposed. 


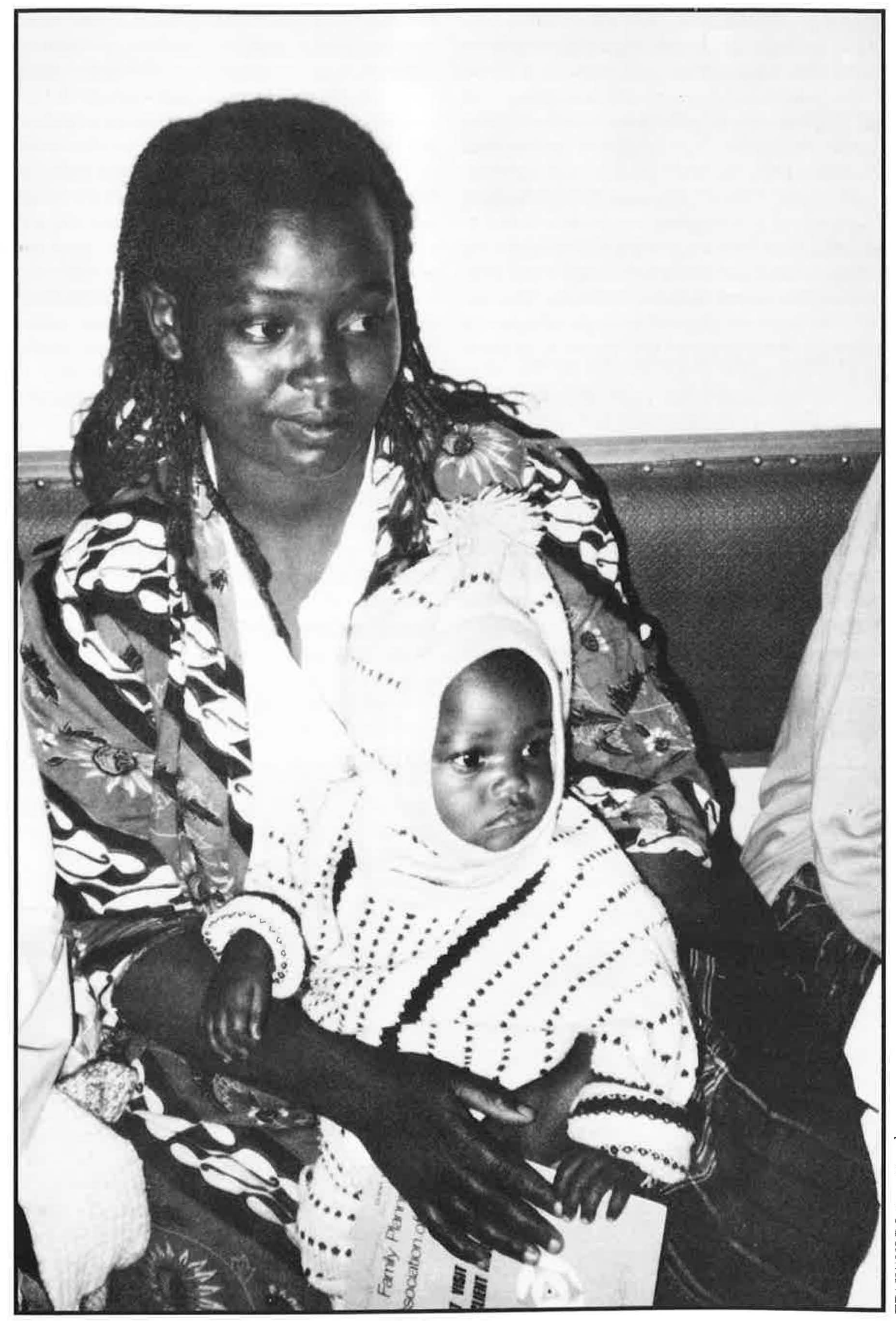


Up until this time, FPAK's activities were highly centralized. Literally each and every letter sent by the organization had to pass through the Executive Director's office. When a nurse from any FPAK clinic applied for leave-no matter how distant she might be from headquarters - only the Executive Director could approve it, in consultation with the Finance Manager and the Medical Director! All new supplies and purchases had to be authorized by headquarters, so inevitably long delays ocurred and staff experienced much frustration. "We began to realize," says Mr. Mzenge, "that we had to let go. . . . Nothing would change unless we were prepared to trust our employees to make decisions for themselves."

On the other hand, clinic staff had never been delegated much authority before, had never been encouraged to assess themselves and the quality of their services, and had never felt inclined to admit their mistakes for fear of retribution. Senior staff realized that delegation of responsibility for improving quality meant more than decentralization, that it would not be feasible without a parallel process of empowerment of the clinic staff.

\section{COPE: A Self-Assessment Technique for Improving Family Planning Services}

It was at about this time that AVSC International was experimenting with a new tool called COPE (client-oriented, provider-efficient), designed to help personnel evaluate their own services and identify ways to make improvements. The COPE technique consists of four main components:

Self-assessment. This is primarily performed with the aid of guides. ${ }^{1}$ Staff use them (1) to evaluate and define their own need for information, training, management and supervisory input, supplies, and a good working environment; (2) to evaluate whether their services address their clients' rights to information, access, method choice, safety, privacy, confidentiality, dignity, comfort, expression, and continuity.

Client interviews. Staff interview 10 clinic clients, asking their opinions about services and what suggestions they have for improvements.

1. Initially these were called checklists; they were redesigned in 1993 and renamed guides.
Usually those interviewed are selected from among clients waiting for services or, occasionally, women are approached just before they leave the clinic. The questions asked relate to clients' overall impression of services at the clinic and not just their own experience on this particular visit.

Client flow analysis. This is a method of tracking clients during their clinic visit. It enables providers to determine how long clients spend waiting for services, where bottlenecks occur, and whether staff time could be used more efficiently.

The plan of action. This is a summary of the other three COPE assessment tools in the form of a written plan. Developed by staff on the last day of COPE, it lists actions to be taken to solve identified problems, persons responsible, and target dates for accomplishment.

Originally COPE was primarily a set of checklists. However; over time it has evolved into a process for change and quality improvement. FPAK's experience using COPE, described below, was an important factor contributing to that evolution.

\section{Using COPE at FPAK: The First Time Around}

When they first heard about COPE, FPAK staff were keen to try it out. So, between 1987 and 1990, they worked with the MOH and AVSC to test it in a few sites. However; the early version of COPE proved to be too focused on the tools themselves and too centered around specific clinic services rather than on staff or client needs. It quickly became apparent that, to be effective, the tools must first work to open up an ongoing dialogue about quality of care, to reallocate decisionmaking power among staff, and to change provider attitudes toward clients. For example, initially all COPE reports had to be sent to headquarters and, because everything was still going to the Executive Director's office, the arrival of these daunting compilations of problems caused great consternation among FPAK management. "Headquarters (HQ) staff wondered why clinics were having so many problems all at once," says Dr. Achwal. "HQ staff would write to the clinics and demand an explanation, even send warning letters that these issues should be resolved at once. The so-called self-assessment exercise was clearly being used in a punitive way."

When it became obvious that this approach 
had failed, FPAK next tried using staff from one clinic to carry out the COPE exercise in another clinic. "This didn't work either; staff felt that they were being spied on, divided, and used," recalls Jane Magu, a receptionist at Phoenix House Clinic. "We did it on the second of January. We found so many problems. It showed us up to be doing a terrible job, very inefficient. ... We thought this had been brought to provide evidence that we should be sacked!"

"We felt very threatened," Alice Ngugi, a nurse at the clinic agrees, "especially as we did it on the second of January. We thought it very inauspicious - what a bad start to the year?"

Along with COPE, FPAK also introduced supervisory checklists and client suggestion boxes. During supervisory visits, staff and supervisors would discuss the supervisor's findings, the COPE results, and the clients' complaints. But no matter how hard supervisors tried to be positive, the discussions still suggested that staff were falling short of the mark.

"The problem was that the staff were still seen as the problem, rather than the solution," says Joseph Dwyer, Africa Regional Director of AVSC International. "A new approach had to be developed, one which really empowered and supported rather than blamed staff, which involved a greater understanding of the quality improvement process by supervisors and HQ staff which sought to emphasize positive rather than negative aspects, and which stressed ownership of the quality improvement tools by the site, not the supervisors."

\section{Using COPE at FPAK: Starting Over}

In 1993, FPAK and AVSC decided to start over. ${ }^{2}$ They took to heart the comments made by Carlos Huezo and Soledad Diaz in an article in Advances in Contraception. ${ }^{3}$

A strategy for quality of care cannot be realistic without recognizing that service providers have their own needs which can be outlined as: training, information, infrastructure, supplies, guidance, back-up, respect, encouragement, feedback, and selfexpression.

Their message was an important one. Clearly staff needs were not being fully explored and personnel were not being encouraged or supported by a facilitative supervisory structure; they did not enjoy the best possible working environment. In other words, staff were expected to provide for clients what they did not have themselves.

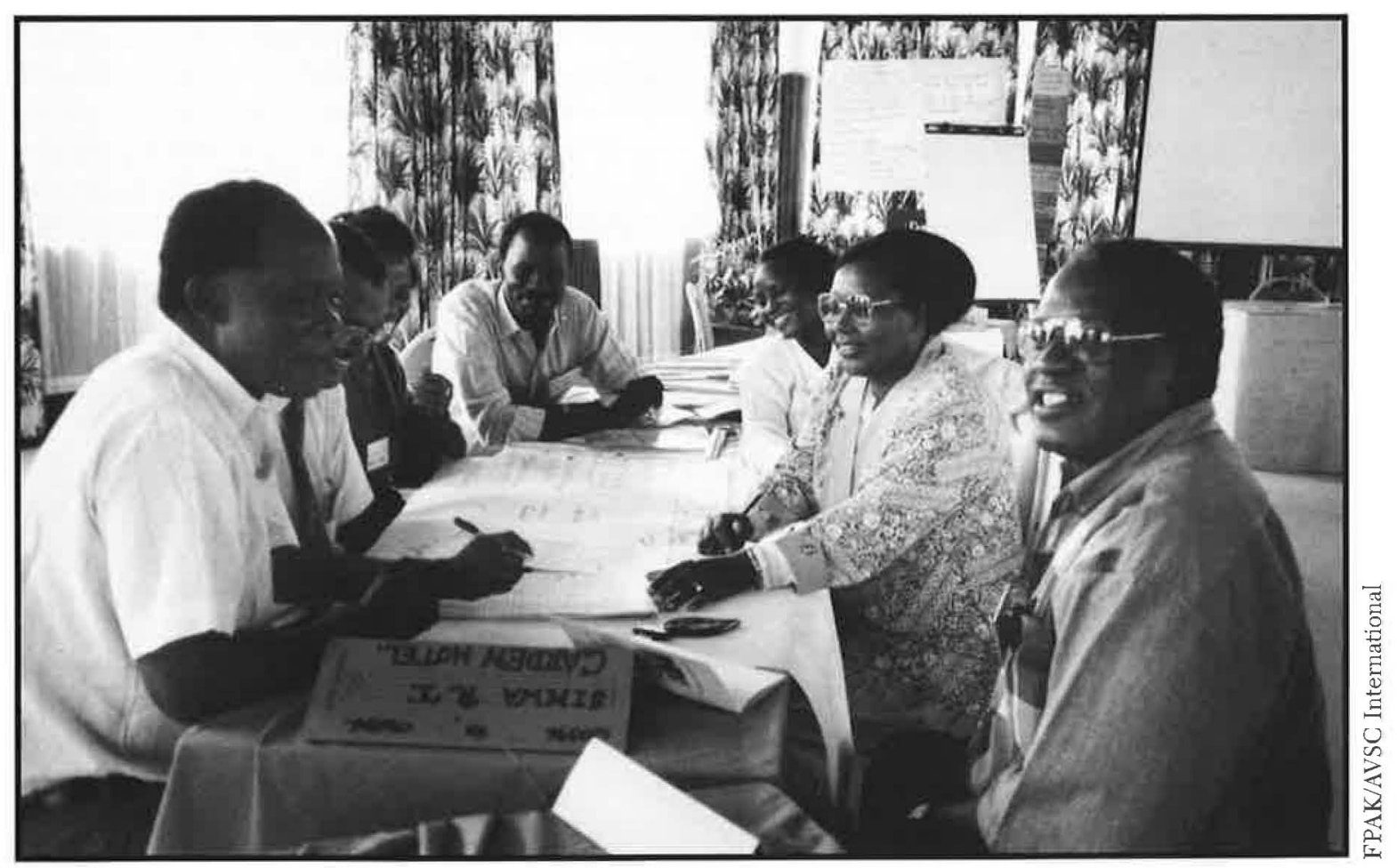


By 1993, international attention began to focus on the notion of clients' rights to quality services. IPPF's poster defining the rights of clients was circulated widely and began to appear on clinic walls around the world, including in Kenya. ${ }^{4}$ Almost immediately FPAK staff could relate to these ideas in terms of their own situation. They began to think about their clients as "customers" who came to the clinic to be served. Explains AVSC International's Grace Wambwa: "How could [the staff] provide information to the clients on a new method if they themselves had never been updated? How could we expect them to provide safe services, decontaminate instruments, and the like, if the need had never been explained and the lotions for decontamination and sterilization were not provided?"

As a result of this new emphasis, AVSC and their Kenyan partners rearranged the COPE selfassessment checklists. Formerly they had been organized functionally around different areas of service provision; now they were reframed as 10 guides, seven devoted to clients' rights and three devoted to provider needs. The self-assessment guides were also made modular in form so that they may be used selectively, their simplicity allowing them to be used routinely and at low-cost.

The way COPE exercises are carried out also changed at this point with local staff being trained to perform the exercises themselves. Completion of a COPE exercise requires that staff divide into groups, each taking responsibility for one of the guides. Each group develops a draft action plan that is brought before the full group for discussion.

When the tools themselves were under review, AVSC found that while the client flow analysis was perceived as useful, it was also considered by staff to be time-consuming and to hold the potential for assigning blame to individuals for the problems that were identified. "We didn't like the CFA at first," says Rebecca Isiche, nurse/midwife at Eastleigh Clinic, "It was too personalized. The exercise shows an individual service provider's contact with clients throughout the day. What it doesn't show is that when you were not with a client, you were sterilizing instruments or sorting out records, or doing other important work." Neither did it improve the quality of the consultations: "We were too concerned with rushing clients in and out so it didn't look as if they had waited too long." Ultimately AVSC suggested that the CFA be given less emphasis, used only when waiting times (or other serious bottlenecks) are perceived to be a problem. However, if a decision is made within a clinic to use the client-flow analysis, it too has been made more user-friendly; data can now be computed locally, as part of the exercise, and then presented to the entire group along with the other information.

In all likelihood, the tools of the exercise will continue to change; supplemental guides dealing with abortion complications, matemity ward issues, breast examinations, Pap smears, and reproductive tract infections are already available. Kalimi Mworia, Associate Regional Director for IPPF and a former Executive Director of FPAK, sums up COPE's appropriateness: "COPE is truly an African invention, molded by people at the cutting edge of service delivery issues. That's why it works." However, the process of implementing COPE has made it clear to FPAK and AVSC that tools alone are not enough. Without change in attitude and a supportive system within which to use them, the tools will be useless. Thus COPE has evolved into a process that now includes many other important elements.

\section{A New Approach to Supervision}

For one thing, the COPE process revealed major problems in the way supervisors' roles were configured. AVSC International's Joseph Dwyer observes, "Services in Kenya were expanding at such a rate that quality improvement and quality assurance could not be the purview of a few supervisors." Supervisors had to learn to be the guides, the motivators, and the facilitators of the process, not the custodians.

My role has changed, says Njagi Muchiri, Area Manager for Nairobi. I have more autonomy than before and that has given me more confidence to support the clinics rather than check up on them. I used to only go to the clinics to find faults, but now I go to support them. My job is to make sure that the clinics have enough supplies, to help them maintain equipment, to troubleshoot, to help with recordkeeping, and to train staff on the job where I can. I feel that they like me more in my new role and that makes my job more rewarding.

While problems still arise as the provider/ 


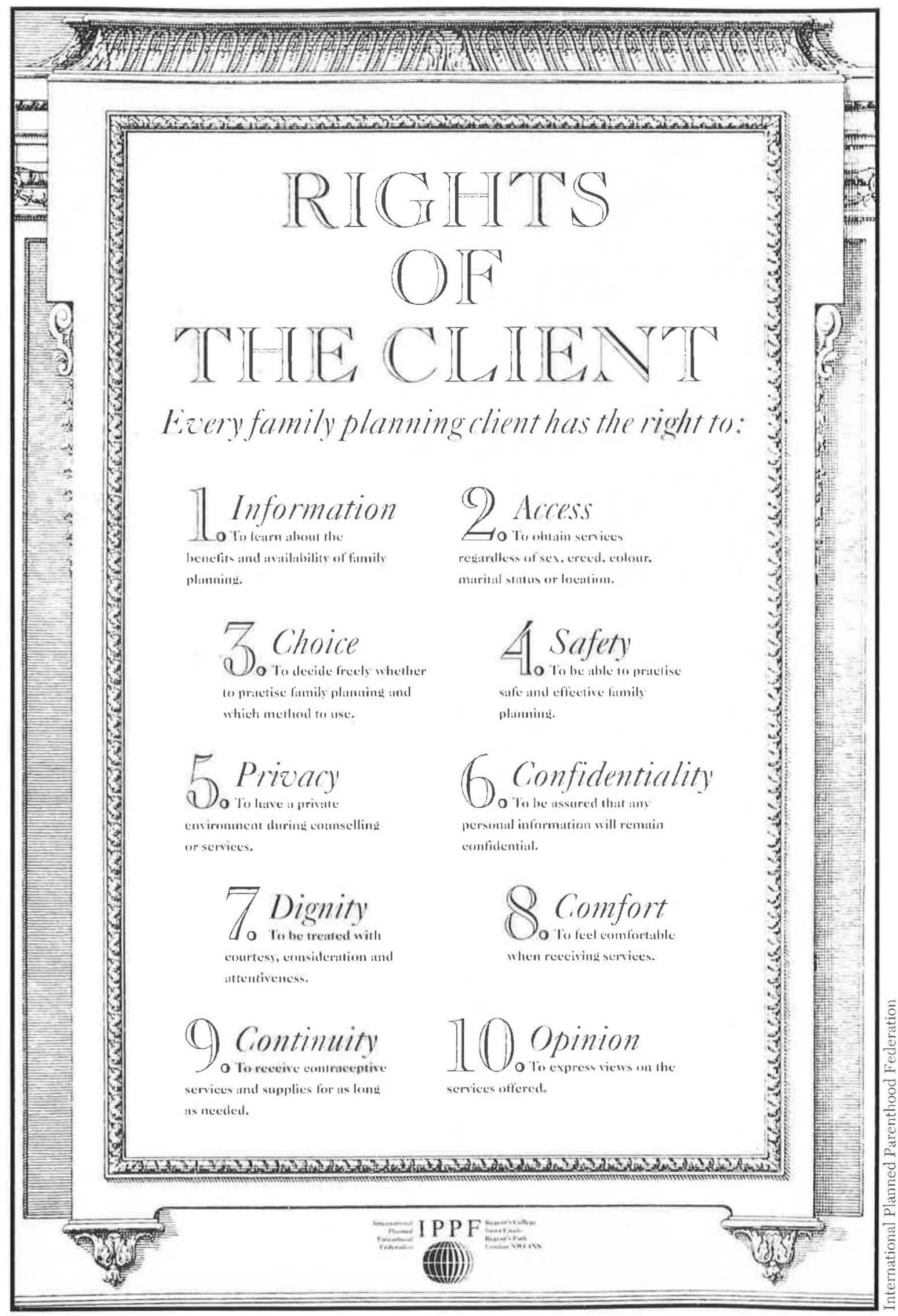


supervisor relationship is being redefined, ultimately most supervisors feel that the role of facilitator is more worthwhile and satisfying than that of inspector.

\section{On-the-job Training}

In carrying out the COPE exercises, poor skill levels were frequently identified as problematic among providers. Up until this point, like most institutions in Kenya, FPAK had relied upon the use of periodic formal, centralized training programs usually held at an off-site location. But FPAK is now convinced that in most cases onthe-job training is a faster; more effective, and less costly means of improving provider skills. Nzioka Kingola, Area Manager for Nyeri, observes: "We have realized that training is not about getting a certificate, but about acquiring knowledge and skills to do a job. Most of that knowledge and skill exists right here-we just need to learn to tap it."

What has been most encouraging is the way in which clinic staff themselves have become avid learners and trainers as well. At FPAK's Nyeri Clinic, the nursing staff (supported by a welltrained supervisor) have trained each other in contraceptive technology, including permanent methods, and in counseling, infection prevention, logistics management, and recordkeeping. Using up-to-date information, they organized all the sessions themselves and the only new cost incurred was for paper. At Phoenix House Clinic, staff have oriented each other to all available family planning methods. They take turns reading the literature about a particular method and presenting their findings to the others. FPAK has facilitated this process by providing some training for

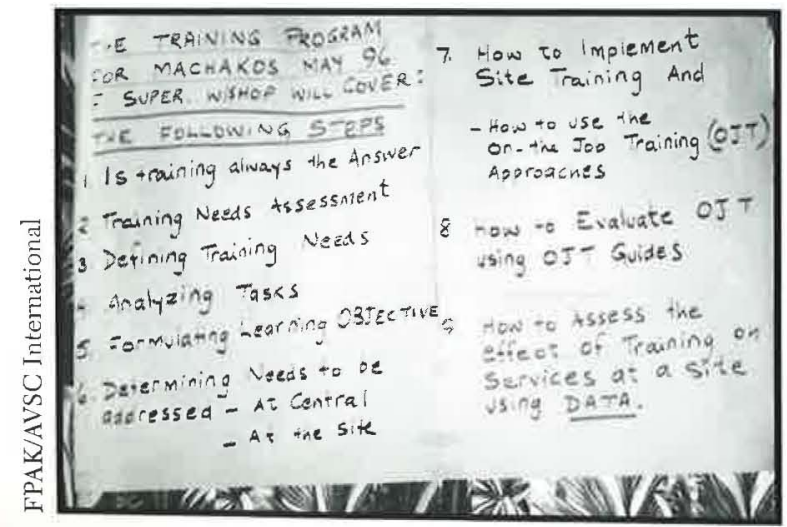

staff in educational techniques and by setting up a small library at each site.

Another benefit of this approach is that it has broken down internal hierarchies. At Ribeiro Clinic, the nurse in charge taught the cleaner/messenger about infection prevention; she showed him how to clean the clinic properly and to autoclave instruments, oriented him to male family planning methods, and encouraged him to talk to clients. "I thought my job here would be just to clean up, but now I have been given confidence to do all sorts of jobs," says Francis Ndungu. In fact, Francis has become so confident that he has led some of the training sessions himself, teaching others about infection prevention, how to use the autoclave, and proper waste disposal. Although incorporation of on-the-job strategies will take a long time to be fully accepted in Kenya-more support from the $\mathrm{MOH}$ (and donors) is required so that they become nationally legitimizedFPAK is convinced they are headed in the right direction.

\section{Ceding Control to the Clinics}

Probably the most significant contribution of FPAK headquarters to the whole COPE process has been decentralized decisionmaking. Staff can now buy equipment locally when they need it instead of having to apply to headquarters for permission. "I still have to account," says Ednah Namiti, "but I'm more able to decide what the money will be spent on. It's much better; I feel that I'm trusted more to do the right thing."

"Decentralization was a gradual process but staff started to work together as teams just as headquarters learned to stop watching over everyone's shoulders," notes Kalimi Mworia. “We had to have the confidence to let go, to change a whole mind-set of control and a feeling that we in HQ were the only ones who knew anything. We had to let them manage the process of change themselves and not force it upon them. I never thought we could do this in Africa, but we did." With this shift in the locus of control, service providers not only began to feel more comfortable with the quality-improvement strategies but also began to feel more valued by the organization.

The data generated through use of the COPE exercises are sensitive. Recognizing this, one of the most important changes FPAK made was to stop insisting that COPE reports always 


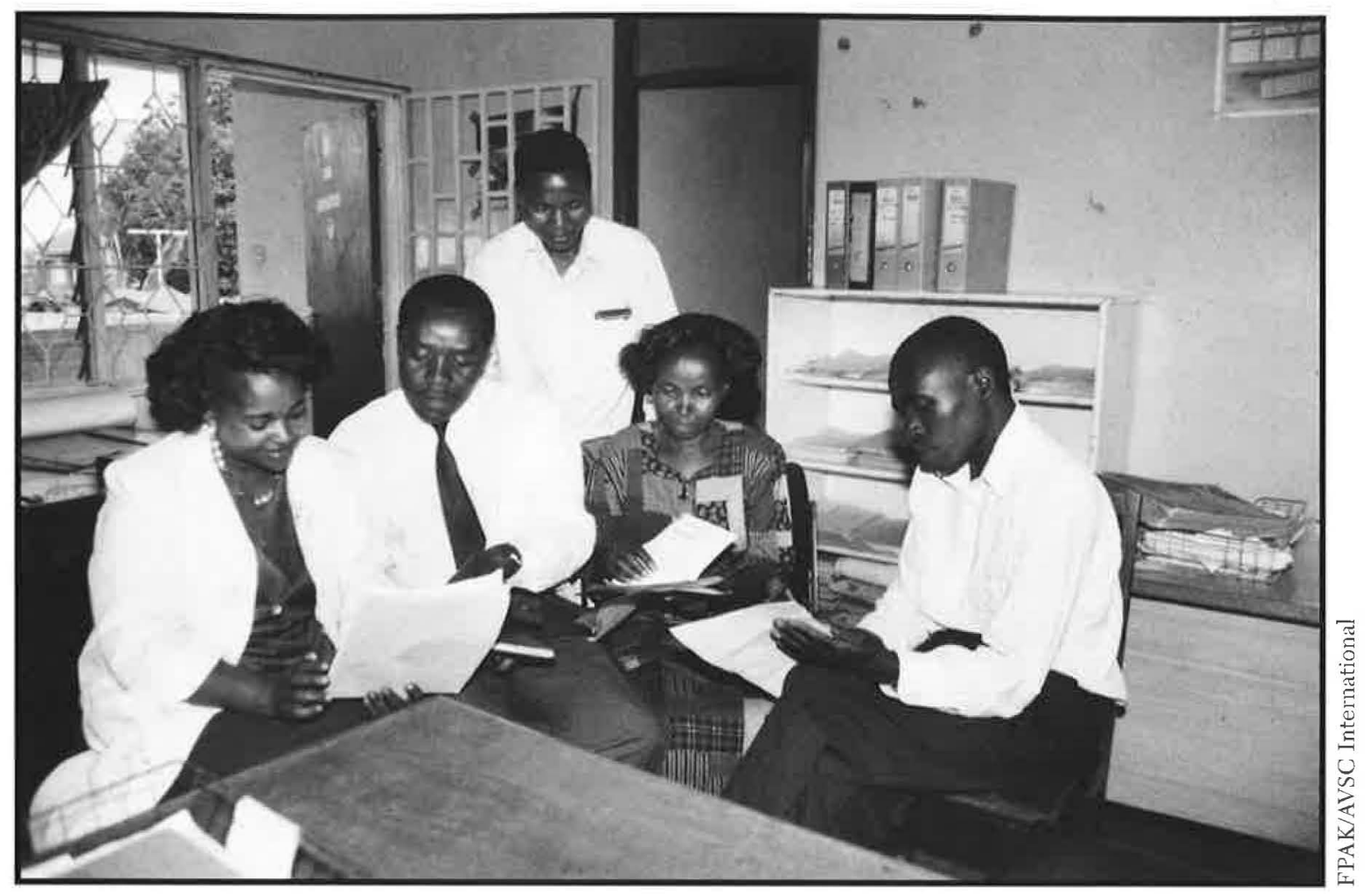

come to headquarters for review. Now these findings are the property of the clinic staff. Similarly, client suggestions are now discussed by clinic staff with their supervisor and staff have been given. more responsibility for taking action to solve the problems they identify.

Today FPAK providers at each site conduct quality-improvement meetings, including undertaking a COPE exercise, every three months. They enjoy using COPE because it belongs to them. "Of course, some things keep appearing on our 'to do' list every quarter; for example, we keep asking headquarters to advertise our clinic more widely," says Rebecca Isiche, a nurse at FPAK's Phoenix House Clinic. "That's frustrating, but you should have seen the long list of problems we had at first and how many we've solved!"

\section{Now We All Work Together as a Team}

Use of COPE encourages all staff to attend and participate in problem-solving sessions. For many, this is the first time they have ever communicated directly with senior staff. "Junior staff feel very privileged and excited to be involved," says Jane Asila of the Ministry of Health. "As we never sat down together and discouraged the clients from complaining, we just carried on in the same way. Even if we thought something was wrong, we were never encouraged to air our views," says Florence Githera of Eastleigh Clinic. "We were losing clients and not even trying to figure out why! And senior staff, although a little resistant at first, soon realized that involving everyone makes their job easier: Where staff have been difficult or uncooperative in the past, they are now starting to plan and work together. Because it's their plan and not the bosses', things start to improve. Then they feel able to support the process!" At Ribeiro Clinic, staff member's take turns facilitating the quarterly COPE exercises so that they feel truly involved and free to express themselves.

The COPE approach encourages all staff to attend meetings; it also encourages true involvement and teamwork. "The COPE approach has changed the traditional chain of command," explains Jane Asila. A government hospital for years had experienced water shortages that threatened the safety of services. After a COPE exercise, the nurses organized a walk through the town where they collected enough funds to sink a new borehole. Now they have enough water to provide safe, clean services, and an operating theater that had 


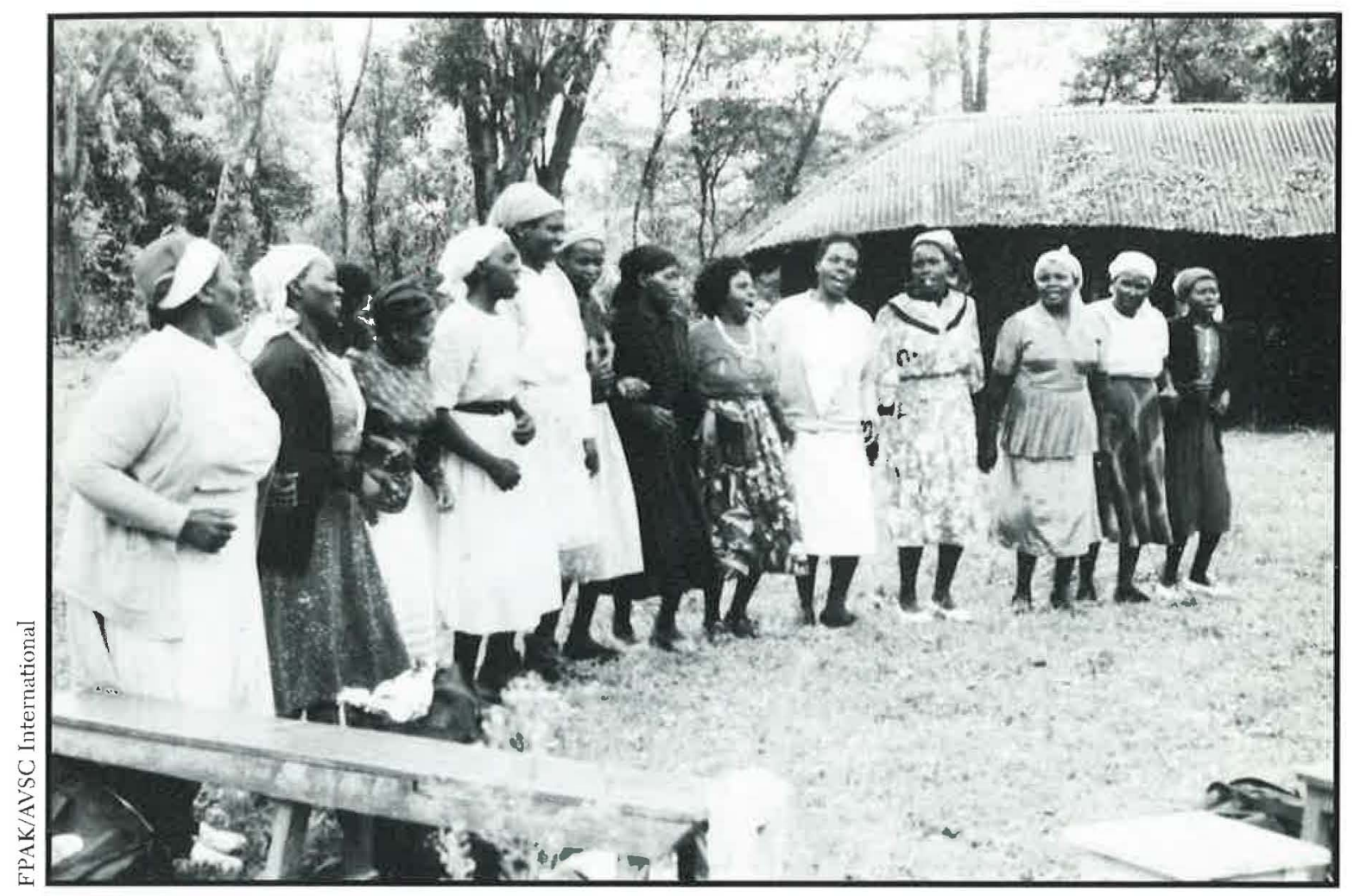

been closed for many years has been reopened.

At Thika Clinic, teamwork has improved noticeably. "Before we adopted this new approach, staff morale was very low, said one staff member. "We didn't even want to see each other. Now we have improved relations so that if, for example, the records clerk is overloaded, other staff come to the rescue to help out." Staff at Eldoret Clinic were surprised at first when it was suggested that drivers and cleaners come to staff meetings. "No one ever asked me before what I thought about services, and I do have ideas," says one of the cleaners. At Nyeri Clinic, gardeners and askaris (watchmen) are also involved and have been given an orientation to family planning. All staff agree this is important, because clients are often given directions by staff working outside. Now, even on weekends, clients can be advised about when to come for services.

The quality-improvement process also seems to have helped staff understand one another and ultimately their clients. As staff at Phoenix House Clinic report:

We realize that we need each other and that we are all individuals with our oun feelings and behaviors that others need to under- stand. ... We all need to help to build each other's confidence and to be friendly to each other. We are doing that at Phoenix House, and it has made a tremendous difference in the way we relate to each other and in the way we treat clients. How can we be civil to clients if we are not, as providers, civil to each other?

The major areas of providers' needs, first described by Huezo and Diaz, were grouped by AVSC into three major categories in the self-assessment guides: (1) good management and supervision; (2) information, training, and development; and (3) supplies and a good working environment. As we have already seen, positive changes are clearly taking place in all three categories. Similarly, clients' rights have been organized into seven major groupings: information, access, choice, safety, privacy and confidentiality, dignity, opinion, comfort, and continuity.

\section{Viewing Clients as "Customers" and Involving Them in the Process}

Involving clients in the process of improving the quality of care has been an interesting and 
important part of FPAK's program. At FPAK clinics today, service providers talk about their desire to relate better to clients, about wanting to hear clients' views, and about creating the sort of services clients will want to recommend to their: friends. "I think we needed to start to see the clients as our customers," says Patricia Muiko, a nurse/midwife at the Phoenix House Clinic.

Use of COPE stimulated FPAK to review previous efforts to seek client feedback. Under the old scheme, suggestion boxes had been placed in waiting areas at all the clinics. However, as Dr. Achwal reports, "Clients weren't told about the suggestion boxes, so we didn't get many suggestions." He adds, "We also used to leave the key with the supervisor, so that he or she, in a sense, controlled things. The boxes would be opened when the supervisor visited and would be used to criticize staff."

Now, after COPE, clients are not only more aware of their rights but also are encouraged to comment on clinic services. A questionnaire has been designed that offers the opportunity for praise as well as criticism. In addition, staff members themselves have become the "owners" of this information; they now hold the key to the suggestion box! As a result, staff are now more open to clients' comments and more willing to make necessary changes.

In addition to written suggestions, as part of quarterly COPE exercises, staff conduct faceto-face interviews with clients. Of course, the results of these interviews are often more positive than negative because of courtesy bias, but the exercise does serve an important purpose. "Our clients feel accepted and treated respectfully here, and they like being given the opportunity to speak their minds freely," says Ednah Namiti at Phoenix House. "Clients tell us that they have noticed improvements," adds another nurse. "They say 'thank you' for safe and quick services; they comment on cleanliness and fresh needles and syringes. It inspires me to greater things!"

The client's right to information. FPAK clinics have always led the way in information, education, and communication work in Kenya. But in recent years, Kenyan women have started to want more information. "They want to know their options; they want to know about infectionprevention practices," says a nurse in Thika. "They come here these days asking how we sterilize our speculums before they'll agree to a Pap smear.
We've educated them to question and to be aware, and that's good."

The range of information provided to clients has also been widened. All FPAK clinics now give talks on breast examination, the importance of Pap smears, sexually transmitted infections, HIV and AIDS, as well as the usual family planning talks. Clinics are quite well supplied with a broad range of client leaflets and posters, although a better requisition system for IEC (similar to that for other equipment) needs to be in place. Many clinics now display the dates of forthcoming talks and they stick to the established schedule. "That way," says Ednah Namiti, "if clients want information on a certain topic, they can arrange which day to come for services." Staff have also come to realize that clients are often too shy to ask direct questions, so staff must initiate the discussion.

The client's right to access and timely service. Before COPE, most of the clinics were only open during weekdays, and then only until 5 p.m., so services were not readily accessible to working women. When staff in Nyeri interviewed clients, they found that many were in favor of the clinics being open on Saturday, so now they are open six days a week, and staff have posted signs all over town advertising the new hours. At

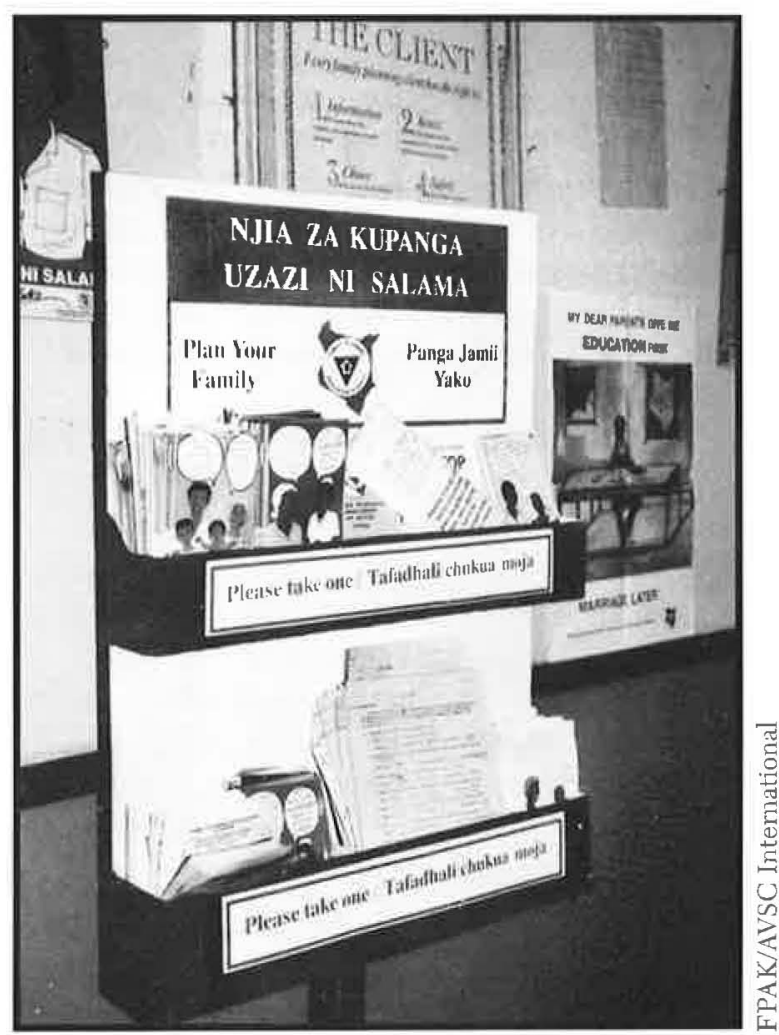




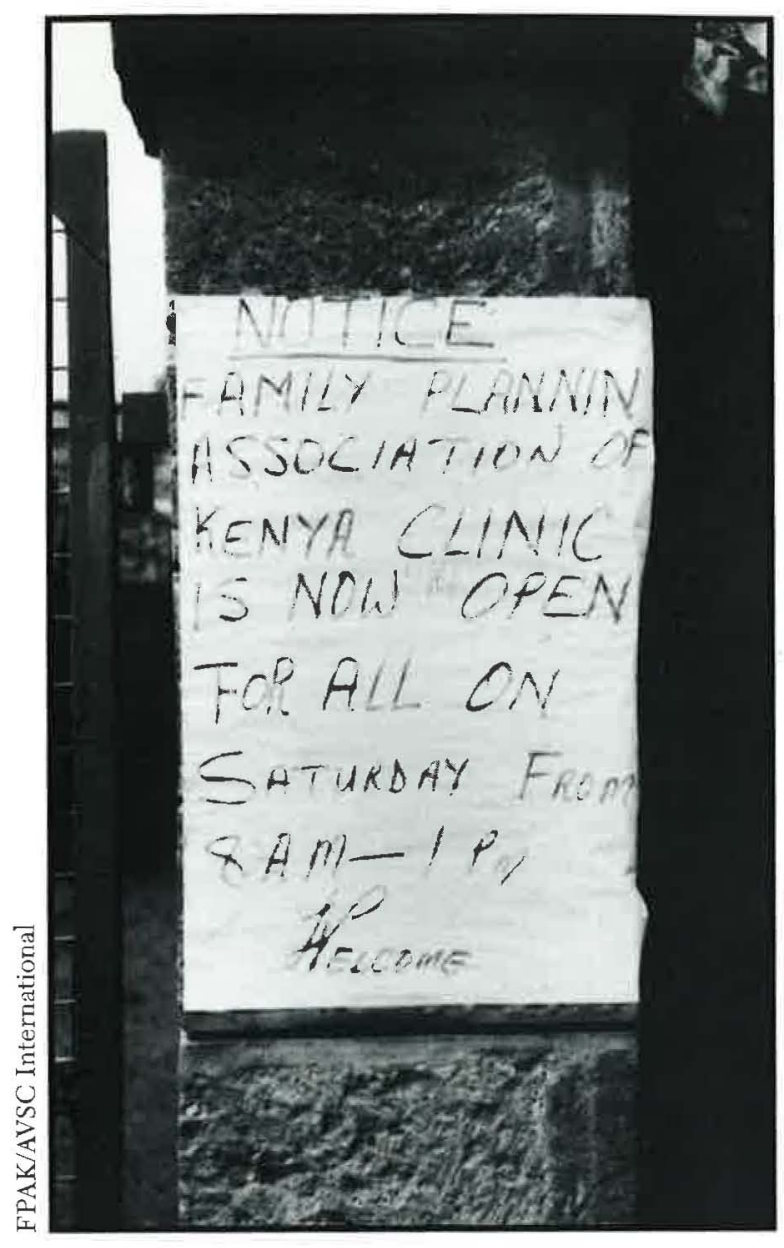

Ribeiro Clinic, near a transportation hub in central Nairobi, staff now keep the clinic open weekdays until 7:00 p.m. and on Saturday mornings. This revised schedule is not only important for working women but also for those rural women who want to combine a trip to the market with a family planning visit.

COPE exercises (particularly the client-flow analysis) also revealed that clients often had to wait for services while staff took lunch breaks. Therefore, at Eastleigh Clinic, staff decided to stagger their lunches rather than stop providing services entirely. Subsequent interviews with clients have shown that this change has been greatly appreciated. In Eldoret, the first time the analysis was conducted, it showed (to the providers' surprise) that clients waited an average of $57 \mathrm{~min}$ utes for service. After a few months, the staff had reduced waiting time to eight minutes-a year later, waiting times were holding steady at about eight and a half minutes.
At Thika Clinic, the main reason for the long waits was that staff were never ready to begin providing services when the clinic opened. As one nurse explains: "The average total time clients used to spend in our clinic was about two hours and 22 minutes. Of this, they waited for two hours and 10 minutes and saw staff for 12 minutes. This was because we always started the day with cleaning of equipment and preparation of the rooms. Then we took long tea breaks and all had lunch together while the clients waited. After the COPE exercise, we decided to clean up and get things ready in the afternoons when most of the clients had gone. This way we could start services at 8 a.m. We also now have shorter tea breaks and stagger lunch breaks. The result is that the client's average time in the clinic is now 35 minutes: waiting for 20 minutes and consultation for $15 \mathrm{~min}$ utes." Other benefits accrue from providing services efficiently. "Now we have time to counsel properly and help people to choose better. We also finish with clients earlier in the day and have time to do staff training sessions, COPE meetings, or other important tasks."

In Nyeri, clients were being kept waiting at the reception area because the receptionist was doing too many jobs at once: retrieving files (which were in disarray), collecting fees, issuing receipts, and the like. In the meantime, the nurses assumed that no more clients were awaiting services. During COPE exercises, the receptionist explained her problems to her colleagues. Now the nurses have started helping with file retrieval and the cleaner/messenger has also been trained to help. At Eastleigh, clients were sometimes kept waiting just because the files were so hard to find. So the nurses decided to sort them out. Each one took a calendar year of records to reorganize, and now file retrieval is no longer a bottleneck.

In most clinics clients wait even longer if for some reason they have to get out of line. Therefore numbered cards are now issued in order to insure implementation of the first-come, first-serve rule. "Sometimes someone goes out of turn for some reason, say for example when they have been waiting for the doctor . . . but we make sure that we explain this to the other clients, so that they can see we operate a fair system," says a clinic nurse in Nyeri.

In fact, when FPAK staff looked at their practices, they realized that some of their protocols were actually denying women services. For 
example, until 1993, FPAK clinics required spousal consent to perform a tubal ligation, even though this is not required by law. Clinic staff decided that, although spousal consent was desirable, it should not be mandatory. "Just as we as providers are being trusted to make decisions, we have to trust our clients, too, and believe that they will do what's right for them." As a result of thought-provoking discussions about women's individual rights, rules regarding the provision of family planning services to unmarried women were also altered.

Recently, access has also been affected by another factor: an increase in fees. For some clinics this has meant a reduction in clientele. But the issue of fair pricing of services, like everything else at FPAK, is open for discussion. Some staff think that the fees are just too high even if the quality offered is good. Staff at Nyeri Clinic, however, disagree. They found that although the number of clients did decline when the fees first went up, after comparing the good-quality of services at FPAK's clinic to what was being offered for free, clients began to come back. They had soon realized that so-called "free" services were, in fact, not free at all, because clients were often asked to provide such essentials as gloves and needles. While most staff accept the inevitability of charging realistic fees to clients, the fee structure remains an issue for further discussion.

The client's right to method choice. The introduction of Norplant in Kenya in 1992-although coincidental to the quality-improvement process under way within FPAK clinics - has provided an important addition to the method mix available to the Association's clients. Norplant removals, however, have been an issue of frequent discussion at quality-improvement meetings. Staff at Eastleigh Clinic, for example, were concerned about the high number of removals requested. After considerable discussion, they realized that they needed to counsel clients more thoroughly about side effects and the long-term nature of the method. Once they started doing this, the number of requests for removals began to decline.

Staff at Phoenix House say training has helped them counsel clients better about all methods. They admit that they used to direct clients to a particular method, and only formally trained counselors could talk to women about permanent methods. At Ribeiro Clinic, staff became aware that they were not sympathetic to clients who wished to switch methods, so now they make a determined effort to acknowledge clients' rights in this area.

The client's right to safe services. The client's non-negotiable right to safety has been reinforced by intensification of infection-protection efforts in light of the HIV/AIDS epidemic. Staff admit that, in the past, they frequently compromised their own health and that of their clients, in part because they were not in control of the quality-assurance process. As one nurse explains, "We were told we had to be more careful and prevent infection, but we were not shown how or given the right materials."

The COPE guides emphasize that infection prevention is everyone's concern. AVSC has provided infection-prevention charts and has helped FPAK organize updates and orientations for all its staff. Once staff became committed to safety, they were quick to request heavy-duty gloves, decontamination buckets, and sterilizing fluids. These changes have led to better protection for clients. "I never" used to even wipe the couch between clients," admits one nurse. "Now I make sure I have everything ready and I do it religiously." Another notes that, "In the old way of doing things, the cleaner, the very person who needs to know about safe waste disposal, would have been left out of any training. Now that person is included, and indeed is often chosen as the one to teach others."

Today FPAK clients are more aware of infection prevention and staff encourage this awareness. Alice Ngugi of Phoenix House recalls that: "Clients used to be so poorly treated, and so they

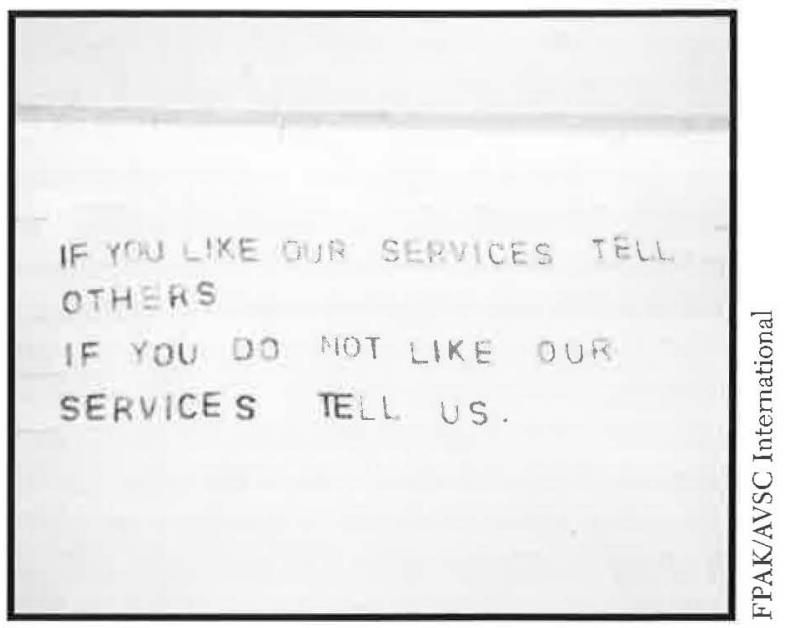


mistrusted our motives as service providers. I think it's essential to be honest with clients; they really want to be more informed. If we' re providing safe services, then why not tell them so? It makes them feel protected and know that we care about them. It makes them come back again, with their friends."

The client's right to privacy and confidentiality. COPE exercises explore the many dimensions of the client privacy issue. After COPE, the Eastleigh Clinic was renovated so that clients could be counseled individually rather than in the same room with others, and most sites now recognize the importance of not interrupting counseling sessions. "We really did use to walk in and out while a client was being counseled," says one nurse, "but we rarely do it now." Staff at Phoenix House Clinic also think back to the days when a woman's file was not her own. "Husbands used to come in here asking about their wives' consultation, and we used to tell them. Now we never would do that...We respect a woman's right to confidentiality and, at the same time, encourage partner involvement and support."

The client's right to continuity. One of the principal causes of the high rates of contraceptive discontinuation in Africa is the unreliable supply of commodities and frequent stock-outs. Before COPE, headquarters did not trust the clinics to keep proper records or to order supplies on time. This led to a tendency to "push" supplies into the clinics, causing overstocking of some items and wastage. But when the COPE exercise was carried out in the Central Stores department, the situation started to improve.

\section{Taking COPE Up the Organizational Ladder}

When COPE was first introduced in the clinics, poor supply of equipment and commodities appeared frequently as a major problem. As a result, FPAK decided to undertake a modified COPE exercise within the Central Stores unit in Nairobi. The exercise revealed that the staff there were just as frustrated with the logistics and supplies system as were clinic staff. "We told ourselves that we were fed up being the butt of everyone's groaning," says Central Stores' Timothy Kioko. "We were in the middle. . . Clinics were complaining, headquarters was complaining, and we couldn't see anything positive about our work. But when it was explained to us how important our job was and that we needed to serve our customers (the clinics) or else women would suffer, we set to work. How can we talk of a quality service if the goods are not delivered on time? We do that now and play a role as quality managers."

The process of empowerment in this department was aided by the willingness of headquarters staff to listen to the constraints the supply unit faced and realize that procedures needed to be changed. Millicent Kabugi of Central Stores recalls, "We designed new requisition forms and ledgers, agreed on minimum stock levels with the clinics, and then went to the clinics and trained staff on the job as to how we needed them to communicate with us. . . Clinics had not been planning so well, but now it's better. . . . We helped them, they helped us, and everyone is much calmer."

In fact, staff in the Central Stores unit became so empowered that they took on IPPF headquarters in London! "Commodities coming from London were often close to expiry," explains Timothy Kioko. "Well of course in the past we just accepted it, we felt grateful for what we were receiving and our attitude was: 'Well these people in London are the big people, who are we to question what they do?' But then we started to use the COPE approach to problem-solving and realized that this was something we had to tackle. What was the point in getting these things that we couldn't use?" The staff wrote a letter to IPPF explaining the problem. "The most recent shipment had a shelf life of five years," beams Timothy. "We sorted it out."

A new supply system has already solved 85 percent of the 41 problems the Central Stores department listed in their first COPE exercise. They have trained clinic staff how to order in a timely fashion, how to assess buffer stocks, and how to use the first in, first out (FIFO) system. (FIFO is a method of organizing commodities so that those received first are also those used first, reducing the chance that they will expire before they are used.) They also helped clinics coordinate supplies to better support the FPAK's CBD agents working in the field. Rebecca Isiche of Ribeiro explains. "COPE has encouraged us to get to know more about the CBD program in our area, and we now see the volunteers as part of our team. We appreciate the fact that they bring us clients." 


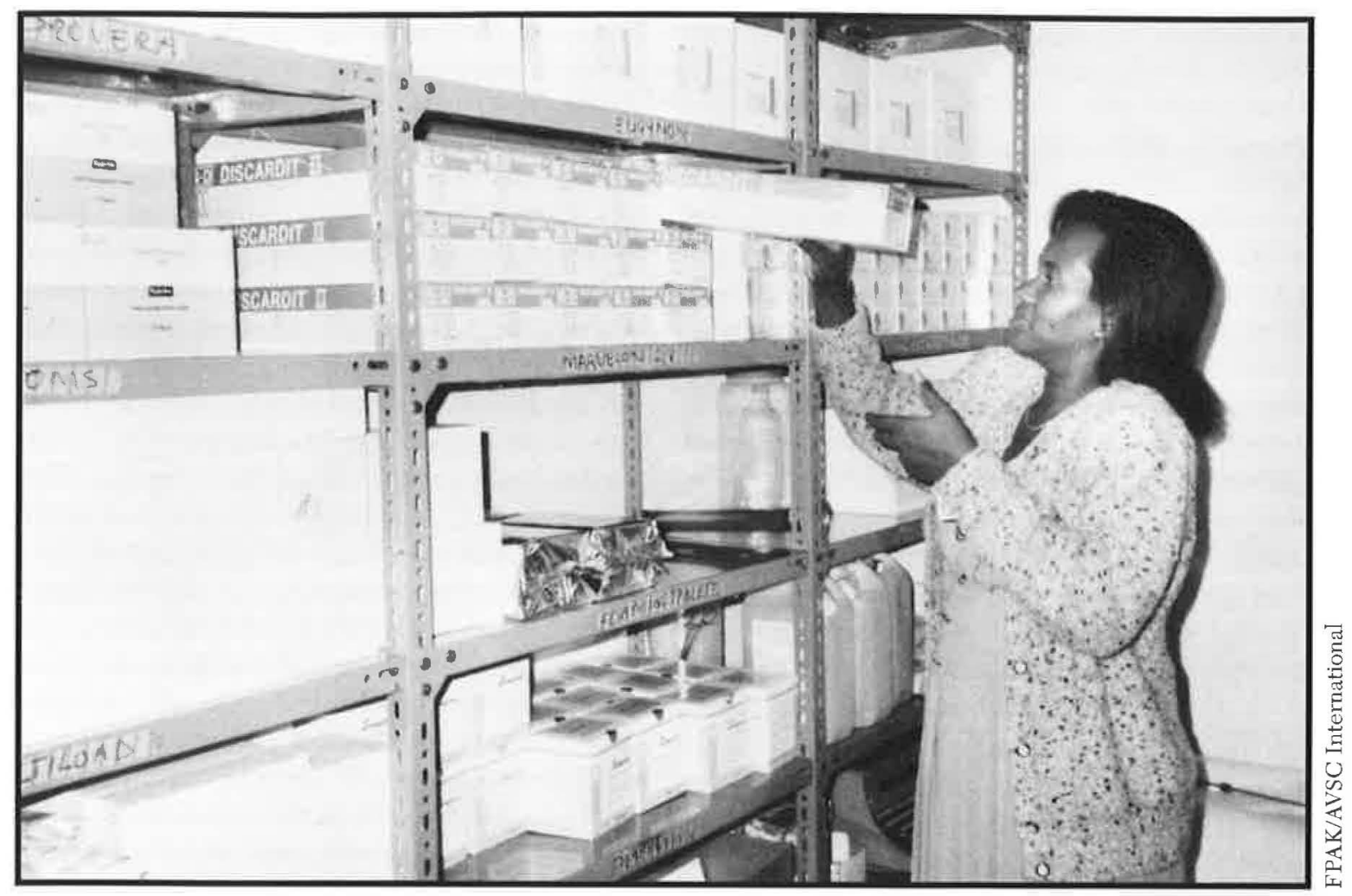

\section{Looking Ahead}

As the FPAK experience clearly demonstrates, quality improvement is not a one-time exercise but an ongoing and ever-changing process. FPAK has been working at quality improvement for more than 10 years, yet only recently has the organization begun to witness real change. Yet the job is still not finished. For example, FPAK headquarters still has not used COPE to assess its own performance. Doing so would be a strong expression of goodwill and could help HQ to support their field staff more effectively. Godwin Mzenge, FPAK's Chief Executive, notes that it still takes 19 steps to get a check issued at headquarters, so they are planning to use the COPE approach when discussing the processes in their Finance Department. Decentralization of financial responsibility - a bedrock issue in systemwide reform -is still in the planning stages. However, prospects are good, especially now that clinics have increased their revenue base not only due to the new fee structure but also because of increasing numbers of clients.

Staff salaries, benefits, and replacement of costly equipment are all issues frequently raised during COPE exercises. To date they have been the sole purview of the central administration, but now these issues too are open to discussion. Some progress has already been made in identifying ways to reward staff in nonmonetary ways, through such iniatives as "employee of the month" and "clinic of the year" recognition. FPAK is pleased with the results of the on-thejob training approach thus far. However, most existing family plamning training materials and curricula have been designed for centralized, formal training programs so available materials need to be carefully reviewed and a reassessment made as to how competency is measured so that staff can receive official recognition for what they have achieved.

Thus far, the program in Kenya has deliberately emphasized problem diagnosis and the use of extremely simple tools that focus on the way people do their jobs. The process has clearly demonstrated that, in addition to identifying a problem, its cause must also be diagnosed and an appropriate solution found. To do this on an everwidening scale, other diagnostic tools such as operations research may need to be introduced. To this end, FPAK staff could benefit from training 
in interpretation and use of the data they are already collecting in their clinics.

\section{Sharing What Has Been Learned}

Observing FPAK's success with COPE, the MOH has now introduced COPE as part of the national improvement plan for family planning in 22 of its hospitals, and is planning eventually to cover all district hospitals and health centers. "We have a big adventure ahead of us," says Jane Asila, "because the uses of this sort of technique and strategy are limitless. It can be used (and has been used) to raise awareness about other issues in our health institutions, not just family planning." In the past two years, FPAK and the Ministry of Health have collaborated on a number of regional quality improvement initiatives. At the national level, inclusion of representatives of the Kenyan Nursing Council in quality-improvement workshops is resulting in increased commitment to quality of care initiatives. Other organizations such as the Christian Health Association of Kenya, Family Planning Private Sector, and Marie Stopes International have also adopted similar qualityimprovement strategies. Outside of Kenya, Dr. Achwal has worked with family planning associations in Eritrea, Nigeria, Tanzania, Uganda, and Zimbabwe, helping them to adopt similar strategies for change.

\section{What Cost Quality?}

When the quality-improvement process began, some FPAK staff felt that it would be costly in terms of staff time and client inconvenience. The COPE exercise takes almost two days to complete, but most of the exercises are conducted while staff continue to serve clients and, as responsibility for carrying out COPE exercises has gradually been transferred to local staff, supervisors now spend less time managing the process and more time providing technical support. Also, as staff began to see the resolution of long-standing problems in their own clinics, their perceptions of "cost" changed. They now realize that there is a price to be paid for not improving quality: dissatisfied customers, underutilized centers, loss of business, declining staff morale. In other words, poor-quality services actually cost more than good-quality care.

\section{Lessons Learned}

1. You cannot legislate quality improvement. When early attempts by management to legislate quality failed, the experience taught both FPAK and AVSC that quality improvement could not simply be mandated. They learned that positive change is, in fact, a process that requires the active participation of all staff, at all levels, within the organization.

2. To achieve real change, management also must be willing to change. The COPE process has helped FPAK headquarters learn that some authority is actually better exercised at the local level and that junior-level staff can make important contributions to solving problems. FPAK has, therefore, evolved from a highly centralized organization to one where at least some financial and management responsibility now rests with area managers and clinic directors, and where clinic staff have been empowered to use information and tools themselves to improve performance.

3 . Staff at all levels, not only service providers, are capable of assuming increased levels of responsibility and contributing to the process of change. For example, use of the COPE process within the Central Stores department had a significant impact on improving the quality of services throughout the organization. At the clinic level, active involvement of other support staff (such as receptionists, cleaners, and the like) has enabled these employees to contribute to the program in meaningful ways that had never before been considered.

4. Viewing clients as "customers" and understanding that your customers have rights, serves to reframe the client-provider relationship. This approach has enabled providers to see things from their clients' perspective and to view them as "people like us." From that perspective, keeping clients waiting while the entire staff took a lunch break clearly was not the right way to treat your customers. In the process, clients are no longer seen as potential sources of criticism but as allies in creating a more positive work experience.

5. Improving the quality of services does not have to mean increased costs. The most common argument for not changing the way services are provided is that change costs too much. Yet a majority of the changes introduced within FPAK through the use of COPE involve 
increasing the efficiency of how existing resources are used rather than increasing the actual investment in service delivery.

6. By involving other organizations in the change process, the quality of services can be affected more broadly, even to the point of contributing to the development of a comprehensive national strategy. FPAK's mutually supportive relationship with the Ministry of Health has done more than legitimize its work. Joint planning for quality workshops, design and testing of tools and strategies, and constant communication and liaison, have meant that a broad spectrum of reproductive health services in Kenya are also benefiting from this process. This changed perspective is already apparent within the scope of national planning to improve delivery of family planning services in Kenya.

\section{Acknowledgments}

The author would like to thank the following for their assistance in preparation of this issue: At FPAK: Godwin Mzenge, Isaac Achwal, Steven Mwangi, Margaret Thuo, and the staff of the Central Stores unit, Eldoret, Phoenix House, Thika, Nyeri, Ribeiro, and Eastleigh Clinics.

At AVSC International: Joseph Dwyer, Grace Wambwa, Pamela Lynam, Karen Beattie, Cynthia Steele, Beverly Ben Salem, and AnnMarie Walker.

For more information about COPE or other quality improvement approaches and materials developed by AVSC, contact Maj-Britt Dohlie, at AVSC International, 79 Madison Avenue, NY, NY 10016 USA. 


\section{Afterword}

The Kenyan experience documented in this edition of Quality/Calidad/Qualité may be unique, but, increasingly, it is being emulated in other parts of the region. Men and women in subSaharan Africa are now taking part in a process of transformation, and are taking control of their fertility in a changing world. I am looking forward to a future in which clients will not only participate more actively in, but are willing to pay for what they view as high-quality services. At a time when donor funding is declining, the challenge of providing sustainable high-quality services is urgent and real. As we approach the 21st century, service providers will be called upon to provide information and to facilitate informed decisionmaking by women, men, and the young people they serve, rather than simply to dispense contraceptives. As we move toward this goal, much work remains to be done and new challenges loom ahead.

Even though services for young people are still viewed as challenging and controversial, we cannot continue to turn a blind eye and a deaf ear to their special needs in the area of sexual and reproductive health. Young people represent at least one of every five women and men of reproductive age in sub-Saharan Africa today, yet they are almost totally excluded by most serviceprovision systems. The result of this neglect is tragically expressed by the high incidence of teenage pregnancies, unsafe abortions, and sexually transmitted infections, including HIV/AIDS, among our youth.

Therefore, we must shift from the narrow perspective of family life education to one of providing holistic and integrated sexual and reproductive health programs and services for young people. Although increasing awareness of these needs has developed within governments and NGOs in the region, their commitment in terms of policies and funding is yet to be expressed. We must address the sexual and reproductive needs of young people honestly and effectively if they are to achieve their full potential as individuals and as tomorrow's citizens.

We must also address the medical and legal barriers that limit access to services and bring about an end to harmful traditional practices that prevent women and young people-especially girls- from achieving their right to enjoy voluntary and safe sexual relationships. Advocacy ini- tiatives for the elimination of female genital mutilation by FPAK and other Kenyan NGOs such as Maendeleo ya Wanawake must be strengthened across the continent. Collaborative studies such as Women of the World: Laws and Policies Affecting Their Reproductive Lives carried out by the Center for Reproductive Law and Policy (New York) and the International Federation of Women Lawyers (Kenya Chapter) F.I.D.A.-K in seven anglophone countries (Ethiopia, Ghana, Kenya, Nigeria, South Africa, Tanzania, and Zimbabwe) have been widely disseminated. ${ }^{5}$ National programs must now use these data to remove the legal and administrative barriers to women's access to safe and noncoercive sexual and reproductive health.

Gender perceptions must be considered and incorporated into our programs as well. Although women-centered and youth-friendly services and the affirmation of clients' rights must continue to be central to all our strategies and innovations, men's roles and responsibilities in sexual and reproductive health also need to be addressed in order for men to become true partners in women's empowerment. In western Kenya, FPAK's male project on sexual and reproductive health and the treatment of sexually transmitted infections is one positive step in this direction.

Finally, we need to rethink, re-examine, and review the delivery of family planning and related reproductive health services in the advent of the HIV/AIDS pandemic. Certainly services for youth offer the potential for early intervention before risky sexual behavior has taken root. But what about those already affected? Community-based approaches to counseling and home-based care will go a long way toward reducing the psychological trauma on the individuals concerned, as well as the heavy burden the epidemic has placed on an already strained health-care system.

The lessons learned through the COPE experience have improved tremendously the image of the service provider within FPAK and its partner organizations. Satisfied clients have spread the word like wildfire in Kenya, and other institutions are knocking on FPAK's door requesting training in the use of COPE. Therefore, we need to create a multiplier effect and extend the benefits not only throughout Kenya, but in sub-Saharan countries as well. Today, for most clients in Africa, quality services still remain a dream. The example set by FPAK and its network, in partnership with AVSC and IPPF, should be emulated in other 
countries. The Kenyan example demonstrates that achieving quality of care and building a culture of self-evaluation and true staff involvement is indeed affordable, attainable, and sustainable within the African context.

\section{Notes}

2. For a summary of this approach, see Dwyer, J. and T. Jerzowski. 1995. "Quality management for family planning services: practical experience from Africa." AVSC Working Paper No. 7, February 1995, AVSC International, New York.
3. Huezo, Carlos and Soledad Diaz. 1993. "Quality of care in family planning: Clients' rights and provider's needs, "in Advances in Contraception 9:129-139.

4. See IPPF, London. 1997. Medical and Service Delivery Guidelines, 2nd edition. IPPF, London.

5. The Center for Reproductive Law and Policy, Inc. and International Federation of Women Lawyers (Kenya Chapter) F.I.D.A.-K. 1997. Women of the World: Laws and Policies Affecting Their Reproductive Lives, Anglophone Africa. The Center for Reproductive Law and Policy, New York. 


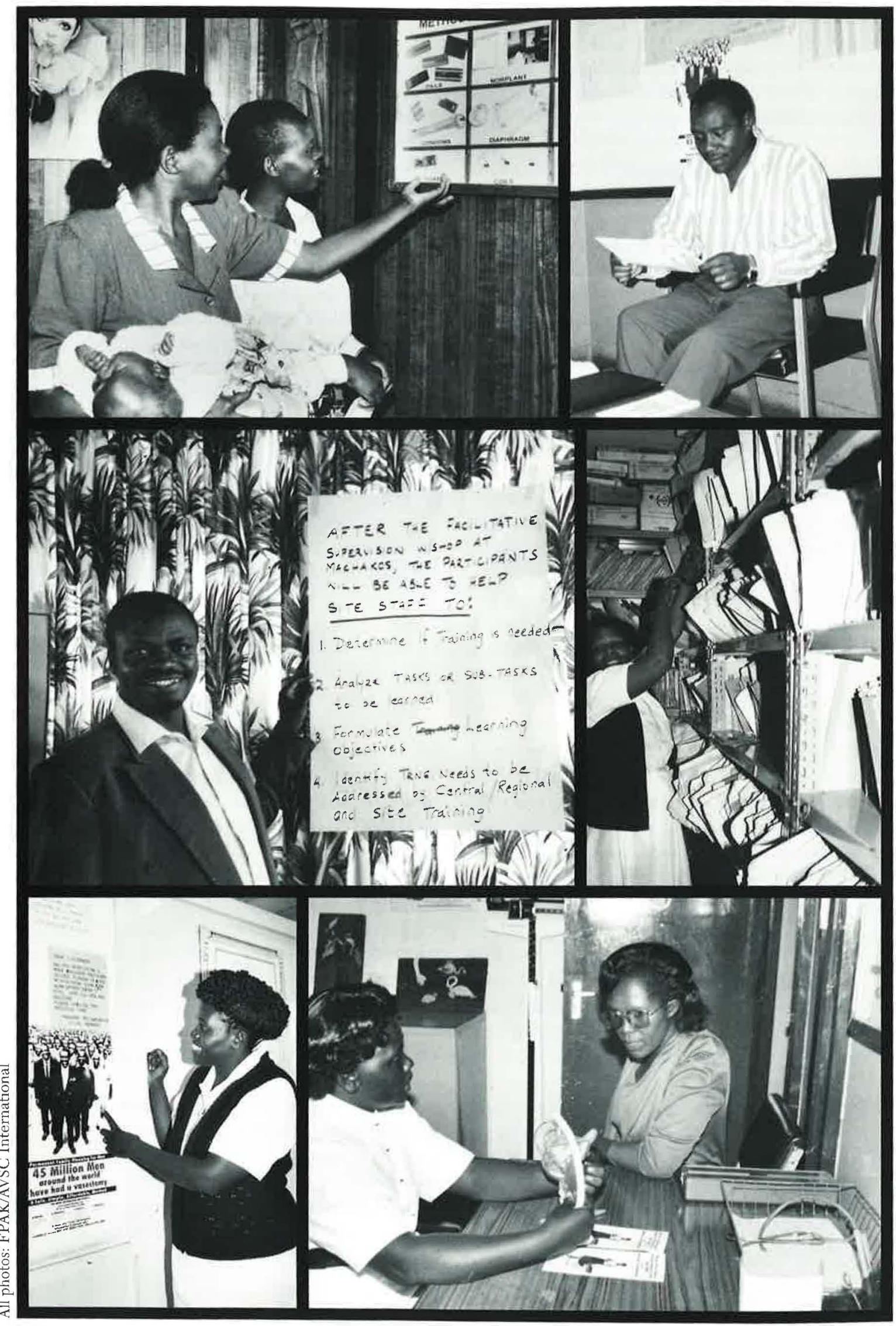




\section{Résumé en français}

Avis au lecteur: Cette publication porte sur l'exercice COPE (client-oriented, provider efficient, services efficaces axés sur le client) de l'AVSC International. Le COPE est un outil d'auto-évaluation qui a été utilisé dans 35 pays, et cette publication examine son emploi par l'association kenyane de planification familiale (FPAK, Family Planning Association of Kenya). Il s'agit de la première d'une série d'éditions décrivant les diverses méthodes qui permettent aux programmes de planification familiale d'évaluer la qualité de leurs services.

La FPAK, organisation affiliée à la fédération internationale pour la planification familiale (IPPF), gère 14 centres de santé au Kenya, soit 250 employés rémunérés travaillant à plein temps et un réseau de plus de 1000 agents bénévoles. Au départ, la FPAK mettait l'accent sur le développement structurel et les objectifs démographiques. Toutefois, au milieu des années 1980 , elle a commencé à déplacer son centre d'intérêt, l'importance de l'offre de soins de qualité se faisant de plus en plus sentir. Les premières tentatives pour résoudre les problèmes n'étaient pas encourageantes, car personne ne voulait prendre la responsabilité des problèmes identifiés.

Dans le même temps, I'AVSC International essayait un nouvel outil d'évaluation appelé COPE (sigle de client-oriented, provider-efficient). La FPAK a accepté d'essayer cette nouvelle méthode pour résoudre les problèmes de qualité des soins. Les exercices COPE comprennent quatre outils fondamentaux : des guides d'auto-évaluation, des entrevues avec les clients, une analyse de l'acheminement des clients (en vue de déterminer les délais d'attente) et un plan d'action rédigé par le personnel, en se basant sur les résultats des trois autres outils d'évaluation.

Il s'est cependant avéré que la première version de COPE était trop axée sur les outils et des services particuliers cles cliniques, et non pas sur le personnel ou les besoins des clients. Par ailleurs, étant donné que les conclusions des exercices COPE étaient directement transmises aux sièges, on continuait d'accuser ou de rejeter la responsabilité des problèmes sur des individus. La FPAK s'est alors rendu compte que le problème provenait non pas des personnes, mais plutôt du système dans lequel ces derniers travaillaient, à savoir un système trop centralisé, n'encourageant pas le personnel, et le punissant parfois. Il fallait adopter une nouvelle approche qui accorderait au personnel le pouvoir d'agir et qui le soutiendrait, plutôt que de le blâmer:

L'AVSC, en collaboration avec la FPAK, a donc reformulé le COPE. La nouvelle approche insistait sur le fait que les outils d'amélioration de la qualité devaient être utilisés par le personnel des centres et non pas par les superviseurs. A cet effet, on a appris au persomnel à faire les exercices COPE, et les rapports n’étaient plus envoyés aux sièges. Les conclusions sont ainsi devenues la propriété du personnel des centres. Ce dernier, ne craignant plus d'être reprimandé, a commencé à analyser les problèmes en toute liberté et à envisager ses propres solutions. La FPAK lui a également domné plus de pouvoir concernant de nombreuses activités. En conséquence, les prestataires de services, qui n'avaient plus peur d'assumer des responsabilités, se sont sentis plus appréciés par l'organisation.

Actuellement, le personnel à tous les niveaux assiste et participe aux exercices COPE. Certains membres du persomel étaient initialement surpris que des chauffeurs, des jardiniers et le personnel de nettoyage soient conviés aux réunions ; ils constatent à présent que ces personnes peuvent aussi contribuer à assurer le succès de la méthode. Le personnel de nettoyage joue désormais un rôle primordial dans le maintien d'un environnement stérile. Les jardiniers et les gardiens, pour leur part, sont en mesure de donner une orientation cle base en matière de planification familiale aux éventuels clients, surtout les hommes.

En outre, la nouvelle approche COPE soutient les droits des clients. Elle fait en sorte que les prestataires s'identifient naturellement avec leurs clients et cherchent à connaître leurs réactions. "Ici, nos clients se sentent acceptés. Ils estiment qu'ils sont traités avec respect et ils sont contents de pouvoir s'exprimer librement," remarque un prestataire. "Les clients nous disent qu'ils ont constaté des améliorations, (cela) me pousse à faire beaucoup plus," ajoute une infirmière.

Au début, certains membres du persomnel de la FPAK pensaient que l'amélioration de la qualité des soins coûterait cher, mais deux jours suffisent pour faire les exercices COPE et la plupart d'entre eux peuvent être effectués pendant que le personnel sert les clients. Ces membres du persomnel s'aperçoivent maintenant que le fait de ne pas améliorer la qualité des services entraine de nombreuses conséquences: clients insatisfaits, centres de santé insuffisamment utilisés, manque de clients et persomel démoralisé.

L'expérience de la FPAK relative à l'emploi de la méthode COPE permet de tirer certains enseignements, notamment que : 1) le changement positif est un processus continu qui nécessite la participation active de tout le personnel à tous les niveaux; 2) certains types de pouvoirs sont mieux exercés par le personnel local que par l'administration centrale ; 3) tous les employés, et pas seulement les prestataires de services, peuvent assumer plus de responsabilités ; 4) le fait de considérer les patients comme des clients ayant des droits peut aider à redéfinir la relation entre le client et le prestataire et 5) en impliquant d'autres organisations dans le processus de changement, on peut améliorer la qualité des services sur une plus grande échelle et même contribuer à l'élaboration d'une stratégie nationale globale. 


\section{Resume en Español}

Nota al lector: Esta edición de SEEDS/CALIDAD/ QUALITE está dedicada a un método de auto-evaluación denominado COPE (en base a la sigla en inglés de "Orientado al Cliente, Eficaz para el Proveedor") y a la experiencia de la Asociación para la Planificación Familiar de Kenia (FPAK) con el mismo. COPE fue desarrollado por la AVSC y ha sido utilizado en 35 países. Esta es la primera de varias ediciones que informarán sobre metodologias que las asociaciones de planificación familiar pueden usar para evaluar la calidad de sus servicios.

FPAK, una afiliada de la IPPF, opera 14 clínicas en Kenia con 250 empleados a tiempo completo y una red de más de 1.000 voluntarios. A mediados de la década de los 80, el énfasis que FPAK originalmente le había puesto al crecimiento institucional y las metas demográficas empezó a cambiar como resultado de una creciente conciencia sobre la importancia de la calidad en la provisión de servicios. Aunque se identificaron varios problemas relativos a la calidad, los primeros intentos en resolverlos no fueron fructíferos, dado que nadie quería tomar responsabilidad.

En esos momentos la AVSC International estaba realizando experimentos con un método de evaluación denominado COPE (orientado al cliente, eficaz para el proveedor). Los dirigentes de FPAK decidieron que estaban dispuestos a probar COPE como una manera más de atender a los problemas de calidad. Los ejercicios COPE tienen cuatro componentes: guías para la auto-evaluación, entrevistas con clientes, análisis del movimiento de clientes (para determinar los tiempos de espera), y un plan de acción redactado por el personal en base a los resultados de las tres herramientas de evaluación recién descritas.

Las primeras versiones de COPE resultaron estar demasiado enfocadas en las herramientas y en los servicios clínicos en sí-en vez de prestarle atención a las necesidades del personal y de los clientes. Y dado que los resultados del COPE eran pasados directamente a los gerentes en la sede de FPAK, la evaluación no hacía nada por eliminar las acusaciones mutuas y la asignación de culpas entre miembros del personal. Fue entonces que los dirigentes de FPAK se dieron cuenta que el problema no estaba con los miembros del personal; al contrario, el problema surgía de la falta de apoyo, la excesiva centralización, y la tendencia punitiva del sistema en que el personal debía trabajar. Era evidente que se necesitaba una nueva manera de practicar la auto-evaluación, una manera que reconociera y celebrara las contribuciones de los empleados en vez de echarles la culpa.

Junto con FPAK, la AVSC empezó a reformular el COPE. La nueva versión empezó por enfatizar que las herramientas para mejorar la calidad le pertenecían al personal, no a los supervisores. El personal aprendió a llevar a cabo los ejercicios COPE por su cuenta y los resultados ya no se mandaron a la sede. Una vez que vieron que los resultados quedaban sólo entre ellos, los miembros del personal dejaron de preocuparse por la posibilidad de recibij amonestaciones y empezaron a analizar los problemas y desarrollar sus propias soluciones. FPAK también decidió darle más autoridad al personal local en cuanto al manejo operacional, lo cual hizo que los empleados se sintieran más capaces cle asumir responsabilidades y, como resultado, que se sintieran más valorados por la organización.

En la actualidad todos los niveles del personal de FPAK participan en los ejercicios COPE. Aunque algunos empleados al principio se sorprendieron cuando los choferes, jardineros y trabajadores de limpieza fueron invitados a participar, hoy se reconoce que ellos también pueden contribuir. Los trabajadores de limpieza ahora son los primeros en asegurar el mantenimiento de condiciones antisépticas, mientras que los jardineros y choferes ahora son capaces de dar una orientación básica en planificacion familiar a clientes potenciales (y especialmente a hombres).

La nueva versión del COPE también apoya los derechos del cliente, al permitir que los proveedores sientan una identificación natural con sus clientes y que les pidan sus comentarios. "Nuestros clientes perciben que los aceptamos y que los tratamos con respeto, y les gusta poder decimos lo que piensan libremente", señala un proveedor: "Los clientes nos dicen que han notado

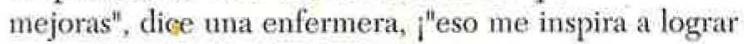
más todavía"!

Al principio algunos de los empleados de FPAK pensaron que mejorar la calidad de atención sería muy caro, pero luego vieron que los ejercicios del COPE requieren sólo dos días para completar y que muchos se pueden llevar a cabo mientras los proveedores siguen atendiendo clientes. Es más, ahora todos entienden que. si no se mejora la calidad también se paga un precio en clientes insatisfechos, clínicas que operan por debajo de su capacidad, pérdida de mercado, y deterioro en el ánimo del personal.

Entre las lecciones que se aprendieron en base a la experiencia de FPAK con el COPE están: 1) El cambio positivo es un proceso de largo plazo que requiere la participación activa de todos los niveles del personal; 2) Hay ciertos tipos de responsabilidades que las unidades locales pueden manejar mejor que la gerencia central; 3 ) Todos los empleados, y no sólo los profesionales, pueden asumir mayores niveles de responsabilidad; 4) Concebir del cliente en el sentido comercial, que otorga derechos al buen servicio, puede ayudar a mejorar la relación entre cliente y proveedor; y 5) Al involucrar a otras organizaciones en el proceso de cambio se puede influir en la calidad de los servicios en una escala mayor, y hasta se puede llegar a contribuir al desarrollo de una estrategia nacional de la calidad. 


\section{About the Authors}

Jan Bradley is currently a Canadian-based population health scientist, with training in health services management, planning, and policy. From 1983 to 1996, she was based in Nairobi, Kenya and worked as a consultant to various local and international agencies. Since the beginning of 1998, she has been a Research Associate at AVSC International.

Judith Bruce is a Senior Associate in the International Programs Division of the Population Council in New York. Soledad Diaz is Senior Scientist at the Social Service Research Unit of the Instituto Chileno de Medicina Reproductiva in Santiago, Chile. Carlos Huezo is Medical Director of the International Planned Parenthood Federation (IPPF), based in London.

Kalimi Mworia is the Associate Regional Director for Advocacy and Resource Mobilization at the IPPF's Africa Regional Office in Nairobi, and the former Executive Director of the Family Planning Association of Kenya.

\section{Quality/Calidad/Qualité Advisory Group}

Ian Askew

Karen Beattie

Martha Brady

George Brown

Judith Bruce

Charlotte Gardiner

Adrienne Germain
Geeta Rao Gupta

Nicole Haberland

Joan Haffey

Judith Helzner

Ann Leonard

Magaly Marques

Elizabeth McGrory
Kirsten Moore

Nancy Newton

John Paxman

Julie Reich .

Deborah Rogow

Jill Sheffield

Cynthia Steele
Karen Stein

Nahid Toubia

Gilberte Vanintejan

Beverly Winikoff
Cover Photo:

Typography:

Printing:
Ann Leonard

Heidi Neurauter

Graphic Impressions

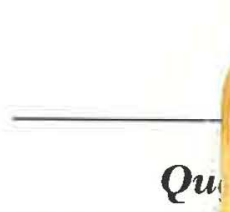

Celebrating Program by

(Available in

Man/Hombr

by Debbie $\mathrm{R}$

(Available in

Gente Joven

Magaly Marc

(Available in

The Coletivo.

Debbie Rogc

Doing More

duction by $\mathrm{C}$
Bradley, Janet.

Using COPE to

improve quality of

care

POPULATIUN LUUIVLIL LIDRARY NEW YORK

\author{
iilable \\ nisia Postpartum \\ y Winikoff, 1989. \\ en format) \\ in Latin America \\ n Leonard, 1990. \\ its in Mexico by \\ dith Bruce, 1993. \\ argarita Diaz and \\ 1 and Portuguese) \\ id Toubia, Intro-
}

Introducing Sexuality within Family Planning: The experence of Inree HIV/STD Prevention Projects from Latin America and the Caribbean by Julie Becker and Elizabeth Leitman, Introduction by Mahmoud F. Fathalla, 1997. (Available in English and Spanish)

(Each English edition contains a one-page summary in both French and Spanish.)

We invite your comments and ideas for projects that might be included in future editions of Quality/Calidad/Qualité. If you would like to be included on our mailing list, please write to Quality/Calidad/Qualité, Population Council, One Dag Hammarskjold Plaza, New York, NY 10017 USA, or e-mail us at pubinfo@popcouncil.org 